\title{
HLA-associated drug hypersensitivity and the prediction of adverse drug reactions
}

\author{
Simone Negrini ${ }^{*}, 1,2$ \& Laurent Becquemont ${ }^{3,4}$ \\ ${ }^{1}$ Department of Internal Medicine, Clinical Immunology Unit, University of Genoa, Genoa, Italy \\ ${ }^{2}$ Center of Excellence for Biomedical Research, University of Genoa, Genoa, Italy \\ ${ }^{3}$ Department of Pharmacology, Hôpital Bicêtre, APHP, Le Kremlin Bicêtre, France \\ ${ }^{4}$ Faculty of Medicine, University Paris Sud; CESP/INSERM U1018 (Centre de Recherche en Épidémiologie et Santé des Populations), \\ France \\ * Author for correspondence: Tel.: +390103538691; Fax: +390105556696; negrini@unige.it
}

\begin{abstract}
Adverse drug reactions are an important cause of morbidity and mortality and constitute the leading reason of drug withdrawal from the market. Besides classical reactions that are related to pharmacologic activity of the drug, some reactions are unpredictable, not dose dependent, and seem to occur in genetically predisposed individuals. The majority of this reaction is immunologically driven and they are referred to as hypersensitivity reactions. A growing number of studies provided evidences that specific HLA alleles increase the risk of developing hypersensitivity drug reactions. In this context, drug hypersensitivities that have more robust pharmacogenetic data include abacavir hypersensitivity syndrome and severe cutaneous adverse reactions induced by allopurinol and carbamazepine.
\end{abstract}

First draft submitted: 23 May 2017; Accepted for publiaction: 19 July 2017; Published online: 11 October 2017

Keywords: abacavir $\bullet$ adverse drug reactions $\bullet$ allopurinol $\bullet$ carbamazepine $\bullet$ HLA $\bullet$ hypersensitivity reactions - pharmacogenomics

Personalized medicine aims to individualize treatment strategies in order to improve the efficacy of therapy and reduce adverse drug reactions (ADRs). Several genetic and nongenetic factors can affect drug responses among individuals, in this scenery, pharmacogenomics is the discipline that studies individual's genetic characteristics that influence drug efficacy and safety. Interestingly, a recent study reported that about $30 \%$ of ADRs are related to drugs with a clinical annotation in the Pharmacogenomics Knowledge Base, suggesting that some of these reactions could have been avoided by pharmacogenetic testing [1]. ADRs are defined by the WHO as an unintended and deleterious response to a pharmaceutical product occurring at a dose normally used in man [2]. In a large historical meta-analysis, Lazarou et al. reported an overall incidence of serious ADRs of $6.7 \%$ and fatal ADRs of $0.32 \%$ in hospitalized patients, and estimated that ADRs are responsible for more than 100,000 deaths annually thus representing the fourth to sixth leading cause of death in the USA [3]. In Europe, it is estimated that $5 \%$ of all hospitalizations and 197,000 fatal cases per year are related to ADRs [4]. Along with the mortality and morbidity impact, the economic cost to society of ADRs amount to $\$ 177$ billion in the USA and $€ 79$ billion in Europe [4,5]. Moreover, ADRs are the leading cause of drug withdrawal from the market thus representing a huge cost burden for pharmaceutical companies [6].

Historically, ADRs are classified into two main categories: Type A ('Augmented') and Type B ('Bizarre') reactions [7]. Type A reactions are predictable, dose dependent, occur in all individuals and could be explained by the pharmacologic activity of the drug (on-target). Type B (off-target) reactions, responsible for at least $15 \%$ of all ADRs, are unpredictable, dose independent and, being related to host genetics, are also named as idiosyncratic reactions' [8]. The majority of type B reactions are driven by the immune system, and they are therefore defined as hypersensitivity drug reactions (HDRs). Based on timing of symptoms onset, hypersensitivity reactions may be further classified as immediate or delayed, suggesting also the immunologic mechanism underlying the reaction [9]. 'Immediate reactions' cause symptoms appearance immediately after drug uptake (mostly $<1 \mathrm{~h}$ ), are IgE mediated and clinical manifestations include angioedema, urticaria, bronchospasm and anaphylaxis. 'Delayed hypersensitivity

Future Medicine 
reactions' typically occur days, or even weeks, after drug exposure and are mediated by T lymphocytes. Delayedtype HDRs include a heterogeneous spectrum of systemic syndromes, also called drug rash with eosinophilia and systemic symptoms (DRESS syndrome) and organ-specific manifestations, most notably cutaneous reactions, and liver injury [8,9]. These HDRs have to be distinguished from autoimmune syndromes induced by the newly released checkpoint inhibitors (e.g., CTLA-4, PD1 and PDL1 antagonist) that are type A ADRs, related to their immunostimulant pharmacological properties and therefore out of the scope of this review.

\section{Immunopathogenic mechanisms involved in HDRs}

MHC molecules play a pivotal role in T-cell activation since this process obligatorily requires that the T-cell receptor (TCR) engages with the complementary antigenic peptide bound to MHC molecules. There are two main families of HLA molecules: MHC class I molecules are expressed by virtually all nucleated cells and present peptides derived from intracellularly expressed proteins to cytotoxic $\mathrm{CD} 8^{+} \mathrm{T}$ cells. MHC class II proteins are typically expressed by professional antigen-presenting cells, such as dendritic cells, and serve to present internalized exogenous protein to $\mathrm{CD}^{+}{ }^{+}$T-helper lymphocytes. The HLA system is the gene complex, located on the short arm of chromosome 6, that encodes MHC proteins in humans. HLA class I molecules are encoded by three loci known as HLA-A, HLA-B and HLA-C, and HLA class II molecules are encoded by HLA-DR, HLA-DQ and HLA-DP genes [10]. The HLA system is the most polymorphic genetic region in the human genome. This variability in HLA molecules results from the need to present a huge variety of peptides. HLA polymorphisms principally influence the shape and electrochemistry of the peptide-binding groove that consequently determine the repertoire of peptides that can bind to a specific HLA molecule. The prevalence of specific HLA alleles differs significantly among different populations and ethnic groups, this phenomenon is linked to the selective pressure exerted by specific factors prevalent in different geographic areas, in particular infectious agents [10,11].

Taking into account the role played by HLA in the adaptive immune response, it is not surprising that certain HLA alleles may predispose to (or protect from) disorders in which the immune system is strongly implicated, such as autoimmunity, cancers or infectious diseases $[12,13]$. Similarly, certain HLA alleles have been associated with an increased risk of delayed HDRs. Since HLA expression is co-dominant, the predisposition to drug hypersensitivity 'simply' depends on the presence of the relevant allele associated to a specific drug. Heterozygote and homozygous individuals have an increased risk of drug-induced hypersensitivity, on the other hand, the absence of the allele indicates that the patient has a very low risk of HDR associated to a specific drug. Consequently, HLA genotyping results are reported as either 'positive' or 'negative', with no intermediate phenotype [10].

As mentioned, $\mathrm{T}$ cells recognize the cognate antigen only if the latter is bound stably in the peptide-binding cleft of the MHC molecule. For this to happen, peptide must have specific dimensional characteristics. However, the large majority of drugs are smaller (molecular weights $<1 \mathrm{kDa}$ ) than the peptide ligands of HLA class I (8-12 amino acids) and class II (9-25 amino acids) molecules, having a size comparable to 1-3 amino acids [14]. Therefore three main immunopathogenic models have been proposed in order to explain how drugs can activate $T$ cells and provoke an immune response. These theories are: the 'hapten/prohapten model', the 'pharmacological interaction (p-i) with immune receptors concept' and the 'altered peptide repertoire hypothesis' (Figure 1). The 'hapten/prohapten model' proposes that a chemically reactive drug, acting as hapten, binds covalently a self-protein (carrier) creating a fully antigenic complex. This neo-antigen is processed by the antigen-presenting cell, loaded onto the HLA molecule and then presented to the cognate $\mathrm{T}$ cell. Similarly, the prohapten is a chemically inert drug that becomes reactive upon metabolism [15]. The 'pi-concept hypothesis' proposes that a chemically nonreactive drug, which is unable to haptenate carrier molecules, can elicit an immune response by interacting directly with the immune receptors (TCR and/or the HLA molecule) independently from the peptide. This interaction needs neither metabolism nor antigen processing [8]. The initial stimulation of the immune receptors is further enhanced by TCR-HLA interaction and probably involves hyper-reactive $T$ cells with a low activation threshold [16-18]. According to the 'altered peptide repertoire hypothesis', a drug binds the antigen-binding cleft of HLA and, modifying its conformation, alters the repertoire of self-peptides that are bound and presented. Since during thymic maturation, $\mathrm{T}$ cells are selected to be tolerant to a specific pool of self-peptides, the presentation of these neo-self-peptides may induce T-cell activation. Recent data suggest that the altered repertoire mechanism is implicated in HDRs related to abacavir and carbamazepine [19]. It is noteworthy that the above-mentioned immunopathogenic theories are nonmutually exclusive and probably a specific mechanism may be prevalent for a given drug but not for another. To date, the best characterized HLA-HDRs associations include abacavir, allopurinol and carbamazepine. 


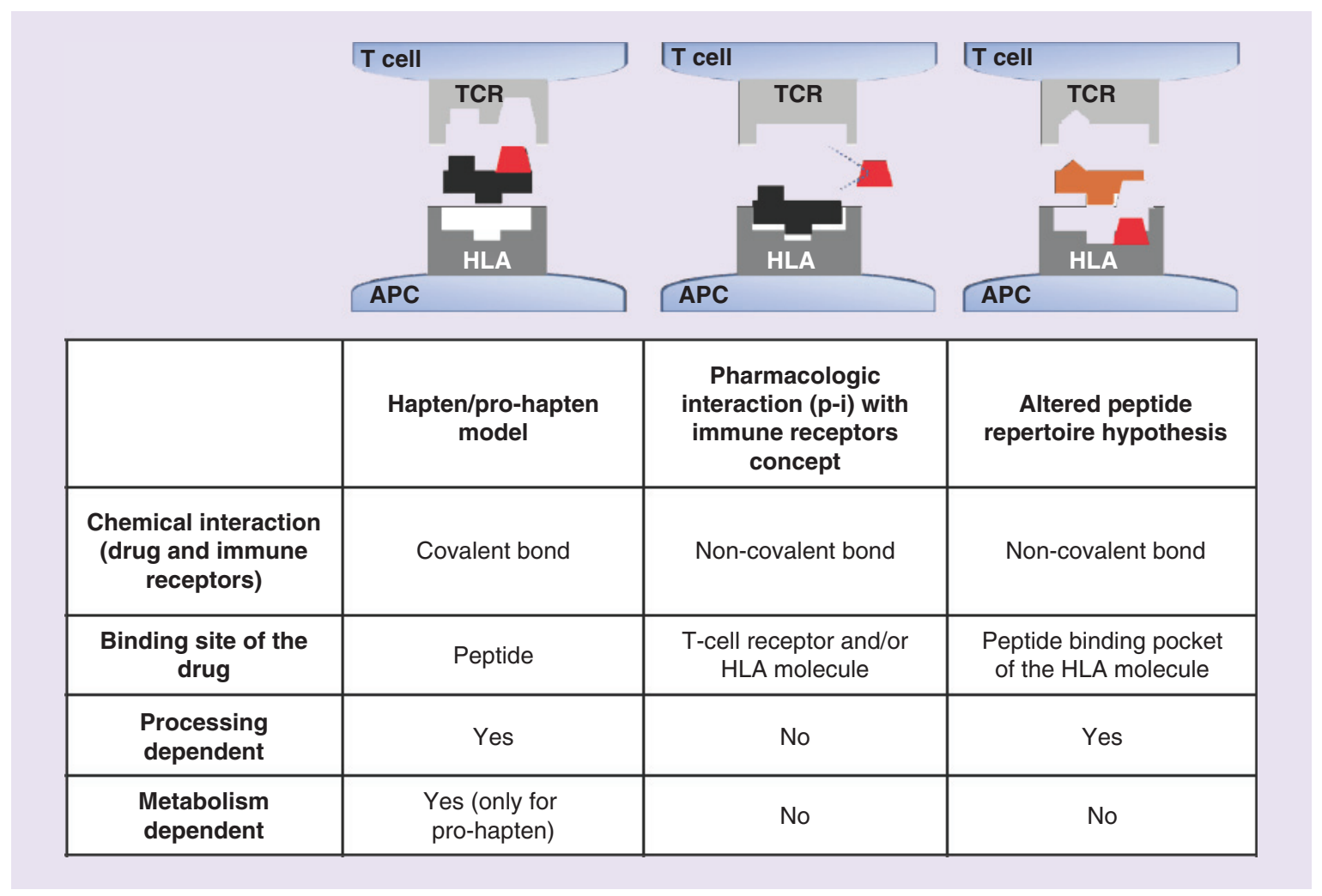

Figure 1. Schematic representation of the immunopathogenic models of T-cell activation by drugs. The repertoire of peptides that can bind to a given HLA molecule is dictated by the shape and electrochemistry of the peptide-binding cleft which in turn depends on its amino acid composition. Hapten/prohapten model, the drug (or its metabolite) binds to self-proteins (carriers) creating a neo-antigen. The latter is processed by the antigen-presenting cell, loaded onto the HLA molecule and then presented to T cells. According to the ' $\mathrm{p}$-i concept', the drug binds directly to MHC molecules and/or TCR, activating T cells. The 'altered peptide hypothesis' suggests that the drug can bind to the HLA-binding cleft and, altering the specificity of peptide binding, change the repertoire of self-peptides presented. This results in the presentation of neo-self-peptides capable to trigger an immune response.

APC: Antigen-presenting cell; TCR: T-cell receptor.

\begin{abstract}
Abacavir
Abacavir is a reverse-transcriptase inhibitor used in combination therapies for the treatment of HIV infection. Abacavir is generally well tolerated, but $5-7 \%$ of exposed patients develop a hypersensitivity syndrome [20]. This syndrome worsens if the treatment is not withdrawn and rechallenge after drug discontinuation can be potentially fatal. The clinical diagnostic criteria for abacavir-induced HDR require at least two symptoms of fever, rash, nausea, vomiting, headache, lethargy, myalgia, arthralgia or gastrointestinal symptoms, occurring within the first 6 weeks of therapy and resolving within $72 \mathrm{~h}$ of withdrawal of the drug. Less frequent manifestations include respiratory symptoms, paresthesia, edema, renal or hepatic failure [21]. Even if abacavir hypersensitivity was described in early phases of drug development, only in 2002, two independent groups reported a strong association between the $H L A-B^{*} 57: 01$ allele and increased risk of developing abacavir-related HDR [22,23]. Thereafter, this association was further reported by other researchers [24-27], but it was definitively confirmed in 2008 with the 'Prospective Randomized Evaluation of DNA Screening in a Clinical Trial 1', the largest randomized clinical trial conducted so far in pharmacogenetics. In this study, 1956 patients from 19 countries were prospectively randomized into two arms: an experimental arm in which $H L A-B^{*} 5701$ carriers did not receive abacavir and a control arm, corresponding to the 'standard of care' at the time of the study, in which patients received the treatment without genetic testing. The incidence of immunologically confirmed (via patch testing) abacavir hypersensitivity reactions was $0 \%$ in the $H L A-B^{*} 57: 01$ negative group as compared with $2.7 \%$ in the control (no screening) group indicating that pretreatment $H L A-B^{*} 5701$ genotyping was capable to effectively prevent hypersensitivity reactions to abacavir [28].
\end{abstract}


Despite these remarkable results, the generalizability of the Prospective Randomized Evaluation of DNA Screening in a Clinical Trial 1 results to all ethnicities was questioned because of the high prevalence of Caucasian in the enrolled population - that is $84 \%$ of the patients. The SHAPE trial, a case-control study enrolling similar percentages of black and white subjects, demonstrated a 100\% negative predictive value (NPV) of HLA-B*57:01 testing for abacavir hypersensitivity for both races, thus confirming the value of the screening across different ethnicities [29]. A recent systematic review and meta-analysis of the literature further confirmed that $H L A-B^{*}$ 57:01 carrier status is significantly associated with abacavir-induced hypersensitivity reactions in Whites, Blacks and Hispanics; in this paper the authors comment that the initially perceived lack of predictive value in non-Caucasians was probably due to the low carriage rate of $H L A-B^{*} 57: 01$, the high rates of false-positive clinical diagnosis of HDR in nonwhite patients and the low number of nonwhite subjects enrolled in early studies [30]. The positive predictive value (PPV) of $H L A-B^{*} 57: 01$ genetic screening is estimated to be around $50 \%$, consequently, approximately half of all $H L A-B^{*}$ 57:01-positive patients actually will never develop the HDR if treated with abacavir indicating that $H L A-B^{*} 57: 01$ is necessary but not sufficient to develop abacavir hypersensitivity. On the other hand, the NPV is $100 \%$, this means that $H L A-B^{*} 57: 01$-negative individuals will not develop hypersensitivity thus making this test very useful for predicting the risk of abacavir-related HDR [28].

This large body of scientific evidence, prompted regulatory agencies, such as US FDA and EMA, and different clinical guidelines to recommend the genotyping for $H L A-B^{*} 57: 01$ before abacavir administration $[31,32]$. The 'real-life' clinical impact of the systematic genotyping in patients candidate for abacavir-based treatments has been acknowledged through follow-up studies which have demonstrated an important decrease in the number of abacavir hypersensitivity cases thus confirming its value and cost-effectiveness [33-36]. At this time, HLA-B*57:01 screening is the most commonly prescribed pharmacogenetic test in clinical practice.

It is worth mentioning that abacavir-specific T-cell responses can be activated only by the $H L A-B^{*} 57: 01$ allele, whereas closely related HLA allotypes such as $H L A-B^{*}$ 57:02 or $-B^{*} 57: 03$ do not. [37]. Conversely, it has been recently reported that HLA- $B^{*}$ 57:02 and $-B^{*} 57: 03$ alleles, but not the $H L A-B^{*} 57: 01$, confer susceptibility to develop liver toxicity in patients receiving antituberculosis and antiretroviral drugs co-treatment [38]. This notion clearly underlines that HLA genotyping should have at least 4-digit resolution (high resolution), because low resolution (2-digit) typing do not allow to discriminate among closely related alleles which may have completely different impact over a specific adverse reaction. Interestingly, the $H L A-B^{*}$ 57:01-related susceptibility to develop HDRs is not limited to abacavir hypersensitivity, in fact this allotype has been also associated with liver injury induced by pazopanib and flucloxacillin, a tyrosine kinase inhibitor and a $\beta$-lactam antibiotic, respectively [39,40]. These data clearly indicate that the same HLA allele may induce clinically different hypersensitivity reactions triggered by chemically unrelated drugs.

\section{Allopurinol}

Stevens-Johnson syndrome (SJS) and toxic epidermal necrolysis (TEN, also known as Lyell's syndrome) are severe bullous mucocutaneous reactions characterized by an extensive skin detachment. The extent of the skin involvement defines the clinical subtype of the disease ( $<10 \%$ in SJS, $10-30 \%$ in SJS/TEN overlap syndrome and $>30 \%$ in TEN) and influence the different prognoses of each of these conditions [41]. SJS/TEN is rare (estimated incidence of 2-6 cases/million per year) but both conditions are associated with significant long-term morbidity, including scarring and blindness, and mortality (rates ranging from 5\% for SJS to 50\% for TEN) [41]. The precise pathophysiology of SJS/TEN is not entirely elucidated, however it seems to depend on the killing of epithelial cells mediated by autoreactive $\mathrm{CD}^{+}$cytotoxic $\mathrm{T}$ lymphocytes through the release of cytolytic mediators (soluble-FasL, granzyme B, perforin, granulysin) and pro-inflammatory cytokines [42-44]. The large majority of cases of SJS/TEN are caused by drugs and several medications are considered at high risk of inducing SJS/TEN [42].

Allopurinol is a xanthine oxidase inhibitor commonly prescribed for the treatment of hyperuricemia-associated disorders, such as chronic gout, uric acid nephrolithiasis and tumor lysis syndrome. Allopurinol is generally considered safe, nevertheless it can induce hypersensitivity reactions, with clinical manifestations ranging from mild cutaneous erythema to most serious conditions which include DRESS and SJS/TEN, the latter occurring in approximately $0.1-0.4 \%$ of the exposed patients [45]. Allopurinol is the most frequent cause of SJS/TEN in Europe, largely surpassing carbamazepine and phenytoin, while in southeast Asia, it is the second most common SJS/TENcausative drug following carbamazepine [46,47]. In 2005, a Taiwanese research group performed a candidate gene analysis comparing 51 patients with allopurinol-induced HDRs with 135 allopurinol-tolerant subjects and 93 healthy subjects from the general population. In this way, they discovered that $H L A-B^{*}$ 58:01 allele was present 
in all patients with allopurinol-induced severe cutaneous ADRs compared with only $15 \%$ of allopurinol-tolerant patients and $20 \%$ of healthy controls [48]. As previously discussed, the presence of $H L A-B^{*} 5801$ in the tolerant group suggests that other contributing factors should intervene in the pathogenesis of hypersensitivity. In this study all the enrolled subjects were of Han Chinese ancestry, but similar results have been further confirmed in other ethnicities: strong association was found in Thais, Japanese and Koreans while a significant but weaker association was reported in Europeans [43,49-53]. This difference might be due to the different allelic frequency of $H L A-B^{*}$ 58:01 across different populations, which is higher in Asian populations (e.g., 20\% in Han Chinese) as compared with Europeans (approximately 1-2\%) and/or additional contributing factors not yet identified. Anyway, a recent meta-analysis confirmed the strong and significant association between $H L A-B^{*}$ 58:01 carrier status and allopurinol-induced SJS/TEN (OR: 96.60 and OR: 79.28 in studies with matched-control or population-control, respectively) in both Asian and non-Asian populations [54].

From an immunopathogenic point of view, allopurinol-related HDR is mediated by $\mathrm{T}$ cells reacting with allopurinol and, more importantly, its metabolite, oxypurinol. Surprisingly, the activation of $\mathrm{T}$ cells reactive to allopurinol and oxypurinol is dose dependent albeit this observation appears in conflict with the dogma that HDRs are unpredictable and dose independent. In fact, a higher starting dose and renal insufficiency (negatively influencing the clearance of the drug) have been indicated as additional risks factor for allopurinol-related HDRs [44,55].

In consideration of the strong association between $H L A-B * 58: 01$ and hypersensitivity reactions to allopurinol across different populations, a genetic screening will be probably adopted in future, nevertheless prospective studies are still necessary to clearly confirm the value of this test in routine clinical practice. To date, FDA and EMA have not implemented allopurinol-labeling information for $H L A-B^{*} 58: 01$ genotyping [31,32]. The Pharmaceuticals and Medical Devices Agency (Japan) package insert only mentions that $H L A-B^{*} 58: 01$ allele is present at a high frequency in patients with SJS/TEN who came from Han Chinese, Japanese or European populations, but pretreatment pharmacogenetic screening is not required or recommended. The Clinical Pharmacogenetics Implementation Consortium guidelines recommend that allopurinol should not be prescribed to patients who are positive for the $H L A-B^{*} 5801$ allele but underscore that a negative genotyping does not exclude the possibility of severe HDRs, especially in European populations [45]. The 2012 revised American College of Rheumatology guidelines for the management of gout also recommend $H L A-B^{*}$ 58:01 screening prior to initiating allopurinol, especially in those populations with high frequencies of the allele (e.g., Koreans with stage $\geq 3$ chronic kidney disease and all those of Han Chinese and Thai descent) [56].

\section{Carbamazepine}

Carbamazepine is an aromatic anticonvulsant used in the treatment of epilepsy, neuropathic pain and bipolar disorder. Carbamazepine has been associated with maculopapular eruption (MPE), DRESS syndrome (also known as drug-induced hypersensitivity syndrome [DIHS]) and less frequently SJS/TEN [10]. These reactions are relatively rare in Western populations (1-6 cases in every 10,000 exposed patients) but occur ten-times more frequently in certain Asian populations, such as Han Chinese [57].

In 2004, Chung et al. described a strong association between carbamazepine-related SJS/TEN and the HLA$B^{*}$ 15:02 allele in Han Chinese patients from Taiwan. They observed that the $H L A-B^{*} 15: 02$ allele was present in all patients with carbamazepine-related SJS/TEN as compared with only $3 \%$ of drug-tolerant subjects and $8.6 \%$ of the general population [58]. Several other studies have confirmed this association in other Asian ethnicities such as Han Chinese from China, Thai, Korean, Malay, Vietnamese and Indian populations [47,59-67]. Three recent meta-analyses that reviewed data obtained from different Asian populations found odds ratios of approximately 80 for carbamazepine-induced SJS/TEN in $H L A-B^{*} 15: 02$ carriers [68-70]. In 2011, the same investigators from Taiwan designed a large prospective study to evaluate the benefits of $H L A-B^{*} 15: 02$ pretreatment screening. In this trial, $4120 H L A-B^{*} 1502$-negative patients were treated with carbamazepine while 215 HLA-B*1502-positive subjects were treated with an alternative drug. The authors observed that SJS/TEN did not develop in any of the treated patients. If compared with the estimated historical incidence of carbamazepine-induced SJS-TEN (0.23\%), the HLA-B*15:02 pretreatment screening effectively prevented ten cases of HDR [71]. These impressive results lay the foundations for the use of $H L A B^{*}$ 15:02 screening before carbamazepine therapy in Asian patients. The observation that not all patients carrying the $H L A-B^{*}$ 15:02 allele develop carbamazepine-associated HDR prompted Ko and colleagues to analyze the TCR repertoire of patients with carbamazepine-induced hypersensitivity [72]. Their study showed that the TCR clonotype, VB-11-ISGSY, was present in 84\% of HLA-B*15:02-positive patients with carbamazepine-associated SJS/TEN but it was absent in all tolerant subjects, including two individuals who 
were $H L A-B^{*} 15: 02$ carriers. These data imply that $H L A-B^{*}$ 15:02 and the VB-11-ISGSY TCR clonotype may synergically contribute to the development of HDR and T-cell activation is not only restricted to specific HLA allotype but also to particular TCR clonotypes [72]. In Caucasian or Japanese populations, HLA-B*15:02 has not been found to be a risk factor in carbamazepine-induced HDR, most likely because this allele has a very low frequency in these ethnic groups $(<1 \%)$. In these populations, recent data report that the presence of $H L A-A^{*} 31: 01$ predisposes to different hypersensitivity phenotypes, including SJS/TEN, MPE and DRESS [68,73-76]. It is worth noting that in Han Chinese, $H L A-A^{*} 31: 01$ allele has been associated with an increased risk of carbamazepineinduced MPE or DRESS, while SJS/TEN are related to $H L A-B^{*} 15: 02$ expression [60,68,77]. These data indicate that genetic predisposition to carbamazepine-triggered HDRs, at least in certain populations, are phenotype-specific. Interestingly, although $H L A-B^{*}$ 15:02 and $H L A-A^{*}$ 31:01 differ greatly from each other in amino-acid sequence, they share two of the three amino acid residues involved in the interaction with carbamazepine, this observation may explain how two different HLA allotype may effectively interact with the same antigen [78]. Besides HLA-B*15:02 and $H L A-A^{*} 31: 01$, other HLA alleles have been reported to increase the risk of carbamazepine-related reactions in various populations (Table 1), however these data are limited and need further verification. Nevertheless, it is interesting to observe that some of these alleles (e.g., $H L A-B^{*} 15: 11, H L A-B^{*} 15: 08$ and $H L A-B^{*} 15: 21$ ) belong to the same $H L A-B 75$ serotype as well as $H L A-B^{*} 15: 02$, suggesting that the members of HLAB75 family may share the ability to bind carbamazepine and activate drug-specific immune response [79].

FDA and EMA have included warnings in the drug label and summary of product characteristic, respectively, recommending $H L A-B^{*}$ 15:02 genetic testing prior to a carbamazepine-based treatment in patients of Asian ancestry [31,32]. Regarding $H L A-A^{*} 31: 01, \mathrm{FDA}$ added a warning to the prescribing information, stating that the risks and benefits of using carbamazepine should be balanced in positive individuals, but pharmacogenetic screening is not currently mandated [32]. Similarly, specific warnings have been included in a number of drug labels worldwide but the association of $H L A-A^{*} 31: 01-H D R$ is mentioned for information only. To date, only the Canadian Pharmacogenomics Network for Drug Safety and the Canadian Department for National Public Health (Health Canada Santé Canada) recommend pharmacogenetic testing for $H L A-A^{*} 31: 01$ prior to carbamazepine in patients of all ancestries [80]. Nevertheless, considering the relative low number of patients needed to be screened to prevent a case of carbamazepine hypersensitivity (47 Caucasians and 67 Japanese patients), it is very likely that $H L A-A^{*} 31: 01$ genetic screening will be implemented in the future [81].

Different studies report that $H L A-B^{*}$ 15:02 could be also related with SJS/TEN induced by other anticonvulsants, such as oxcarbazepine, phenytoin and lamotrigine [60,68,82]. These findings suggest that $H L A-B^{*} 15: 02$ carriers may show cross-reactivity to aromatic antiepileptic drugs, other than carbamazepine, and consequently special attention should be given when considering antiepileptic treatment for $H L A-B^{*} 1502$-positive patients [83]. At present, FDA recommends to avoid phenytoin as an alternative for carbamazepine in $H L A-B^{*} 1502$ carriers, and suggests testing for $H L A-B^{*} 1502$ allele prior to oxcarbazepine in patients with ancestry in genetically at-risk populations (e.g., Han Chinese and Thai, Philippines and Malaysian populations). To date, FDA does not provide specific recommendations concerning lamotrigine [32].

\section{Conclusion \& future perspective}

Abacavir, carbamazepine and allopurinol are key examples of pharmacogenetics implementation in routine medical practice demonstrating to be both clinically useful and cost effective [84], but a huge number of other HLArelated HDRs have been described to date (Table 1). A complete listing is available on the Pharmacogenomics Knowledge Base website [85,86]. Successful clinical implementation of a specific pharmacogenetic biomarker can be schematically resumed in four phases: discovery, clinical validity and utility, implementation and positive effect on public health [87]. However, the large majority of the HLA-drug-HDR associations described so far are still relegated in a preliminary phase (discovery) and thus need further investigation to confirm their translational potential.

Several concerns should be taken into consideration before HLA-HDR associations could be successfully translated in screening procedures. In this context, it is interesting to observe that $10 \%$ of drug labels contain information on genetic factors influencing drug safety, but only a limited number of genetic tests are presently employed in clinical routine [88]. Factors influencing the translatability of a given pharmacogenetic testing into clinical practice have been extensively analyzed by different authors [87,89-90]. Concerning HLA-related HDR pharmacogenetic testing, the main critical issues are: drug toxicity should be severe and frequent, NPV (and ideally also the PPV) should reach 100\%, the incriminated HLA allele should be sufficiently frequent inside the target 
Table 1. Most significant pharmacogenomics associations between classical HLA allelic variants and drug hypersensitivity reactions (source Pharmacogenomics Knowledge Base database).

\begin{tabular}{|c|c|c|c|c|c|c|}
\hline Drug & $\begin{array}{l}\text { PharmGKB } \\
\text { level of } \\
\text { evidence }^{\dagger}\end{array}$ & Allele-haplotype & $\begin{array}{l}\text { Clinical mani- } \\
\text { festation(s) }\end{array}$ & Population(s) & Risk of ADR & Clinical implementation \\
\hline Abacavir & $1 \mathrm{~A}$ & $H L A-B * 57: 01$ & DRESS & $\begin{array}{l}\text { Mixed } \\
\text { population }\end{array}$ & Increased & $\begin{array}{l}\text { FDA: boxed warning, test required, } \\
\text { EMA: testing required, } \\
\text { PMDA: label information, } \\
\text { HCSC: testing required, } \\
\text { DPWG: alternative drug for positive patients, } \\
\text { HIV Treatment Guidelines and National } \\
\text { Authorities: testing required or recommended }\end{array}$ \\
\hline Acetazolamide & 4 & $H L A-B * 59: 01$ & SJS/TEN & Asian (Korean) & Increased & $\mathrm{N} / \mathrm{A}$ \\
\hline Acetaminophen & 3 & $H L A-D Q B 1 * 02: 02$ & SJS/TEN & $\begin{array}{l}\text { Caucasian } \\
\text { (Italian) }\end{array}$ & Increased & $\mathrm{N} / \mathrm{A}$ \\
\hline \multirow[t]{11}{*}{ Allopurinol } & $1 \mathrm{~A}$ & $H L A-B * 58: 01$ & SJS/TEN & $\begin{array}{l}\text { Mixed } \\
\text { population }\end{array}$ & Increased & $\begin{array}{l}\text { European national competent } \\
\text { authorities: warning (no genotyping } \\
\text { recommendations), } \\
\text { ACR: alternative drug for } H L A-B * 58: 01 \text {-positive } \\
\text { patients, } \\
\text { PMDA: label information }\end{array}$ \\
\hline & $2 \mathrm{~B}$ & $H L A-A * 33: 03$ & $\begin{array}{l}\text { Drug } \\
\text { hypersensitivity, } \\
\text { SJS/TEN }\end{array}$ & $\begin{array}{l}\text { Mixed } \\
\text { population }\end{array}$ & Increased & \\
\hline & $2 \mathrm{~B}$ & $H L A-C^{*} 03: 02$ & SJS/TEN & $\begin{array}{l}\text { Mixed } \\
\text { population }\end{array}$ & Increased & \\
\hline & 3 & $H L A-A * 02: 01$ & SJS/TEN & Asian & Decreased & \\
\hline & 3 & $H L A-B * 48: 01$ & $\begin{array}{l}\text { Drug } \\
\text { hypersensitivity }\end{array}$ & Asian & $\begin{array}{l}\text { Increased (not in all } \\
\text { studies) }\end{array}$ & \\
\hline & 3 & $\begin{array}{l}H L A-C^{*} 03: 02 \text { (and } \\
\text { chronic renal } \\
\text { insufficiency) }\end{array}$ & Skin rash & Korean & Increased & \\
\hline & 3 & $H L A-C^{*} 08: 01$ & $\begin{array}{l}\text { Drug } \\
\text { hypersensitivity }\end{array}$ & $\begin{array}{l}\text { Mixed } \\
\text { population }\end{array}$ & $\begin{array}{l}\text { Increased (not in all } \\
\text { studies) }\end{array}$ & \\
\hline & 3 & $\begin{array}{l}H L A-D Q B 1 * 05: 02- \\
H L A-D R B 1 * 15: 02 \\
\text { haplotype or } \\
H L A-D R B 1 * 13: 02- \\
H L A-B * 58: 01 \\
\text { haplotype }\end{array}$ & SJS/TEN & $\begin{array}{l}\text { Caucasian } \\
\text { (Italian) }\end{array}$ & Increased & \\
\hline & 3 & HLA-DR9; HLA-DR14 & MPE & Asian & Increased & \\
\hline & 3 & $\begin{array}{l}H L A-D R B 1 * 03: 01 \text { (in } \\
\text { LD with } H L A-B * 58: 01 \\
\text { in some populations) }\end{array}$ & SJS/TEN & $\begin{array}{l}\text { Asian (Han } \\
\text { Chinese) }\end{array}$ & Increased & \\
\hline & 3 & $\begin{array}{l}H L A-D R B 1 * 14: 01 \\
H L A-D R B 1 * 09: 01\end{array}$ & $\begin{array}{l}\text { Drug } \\
\text { hypersensitivity }\end{array}$ & Asian & Increased & \\
\hline \multirow[t]{2}{*}{$\begin{array}{l}\text { Amoxicillin- } \\
\text { clavulanate }\end{array}$} & 3 & $H L A-B * 18: 01$ & $\begin{array}{l}\text { Drug-induced } \\
\text { liver injury }\end{array}$ & Caucasian & Increased & $\mathrm{N} / \mathrm{A}$ \\
\hline & 3 & $\begin{array}{l}\text { rs9274407 } \\
(H L A-D Q B 1)\end{array}$ & $\begin{array}{l}\text { Drug-induced } \\
\text { liver injury }\end{array}$ & White & $\begin{array}{l}\text { TT genotypes have } \\
\text { a decreased risk } \\
\text { while AT and AA } \\
\text { genotypes have an } \\
\text { increased risk }\end{array}$ & \\
\hline Asparaginase & 3 & $\begin{array}{l}\text { rs17885382 } \\
(H L A-D R B 1)\end{array}$ & $\begin{array}{l}\text { Asparaginase } \\
\text { hypersensitivity } \\
\text { (precursor cell } \\
\text { lymphoblastic } \\
\text { leukemia- } \\
\text { lymphoma) }\end{array}$ & $\begin{array}{l}\text { Pediatric mixed } \\
\text { population }\end{array}$ & $\begin{array}{l}\text { AA genotypes have } \\
\text { a decreased risk } \\
\text { while AT and TT } \\
\text { genotypes have an } \\
\text { increased risk }\end{array}$ & $\mathrm{N} / \mathrm{A}$ \\
\hline Aspirin & $2 B$ & $H L A-D P B 1 * 03: 01$ & Asthma & $\begin{array}{l}\text { Mixed } \\
\text { population }\end{array}$ & Increased & N/A \\
\hline \multicolumn{7}{|c|}{$\begin{array}{l}\text { †PharmGKB levels of evidence for clinical annotations. Levels of evidence vary from } 1 \text { (robust data, most important associations) to } 4 \text { (less-consistent associations). PharmGKB curators } \\
\text { periodically review the level of evidence of clinical annotations, therefore, the level of evidence may change over time as a result of additional studies performed. } \\
\text { ACR: American College of Rheumatology; ADR: Adverse drug reaction; CPIC: Clinical Pharmacogenetics Implementation Consortium; CPNDS: Canadian Pharmacogenomics Network } \\
\text { for Drug Safety; DILI: Drug-induced liver injury; DPWG: Dutch Pharmacogenetics Working Group; DRESS: Drug reaction with eosinophilia and systemic symptom; HCSC: Health Canada } \\
\text { (Santé Canada); MPE: Maculopapular eruption, N/A: Not applicable; PharmGKB: Pharmacogenomics Knowledge Base; PMDA: Pharmaceuticals and Medical Devices Agency - Japan; } \\
\text { SJS: Stevens-Johnson syndrome; TEN: Toxic epidermal necrolysis. }\end{array}$} \\
\hline
\end{tabular}


Table 1. Most significant pharmacogenomics associations between classical HLA allelic variants and drug hypersensitivity reactions (source Pharmacogenomics Knowledge Base database) (cont.).

\begin{tabular}{|c|c|c|c|c|c|c|}
\hline Drug & $\begin{array}{l}\text { PharmGKB } \\
\text { level of } \\
\text { evidence }^{\dagger}\end{array}$ & Allele-haplotype & $\begin{array}{l}\text { Clinical mani- } \\
\text { festation(s) }\end{array}$ & Population(s) & Risk of ADR & Clinical implementation \\
\hline & 3 & $H L A-D P B 1 * 04: 01$ & Asthma & $\begin{array}{l}\text { Mixed } \\
\text { population }\end{array}$ & Decreased & \\
\hline & 3 & $\begin{array}{l}\text { rs3129294 } \\
(H L A-D P B 2)\end{array}$ & Asthma & Asian & $\begin{array}{l}\text { AA genotypes have } \\
\text { a decreased risk } \\
\text { while } A C \text { and } C C \\
\text { genotypes have an } \\
\text { increased risk }\end{array}$ & \\
\hline $\begin{array}{l}\text { Azathioprine (or } \\
\text { mercaptopurine) }\end{array}$ & 3 & $\begin{array}{l}H L A-D Q A 1 * 02: 01 \\
H L A-D R B 1 * 07: 01\end{array}$ & Pancreatitis & European & Increased & $\mathrm{N} / \mathrm{A}$ \\
\hline \multirow[t]{13}{*}{ Carbamazepine } & $1 \mathrm{~A}$ & $H L A-B * 15: 02$ & SJS/TEN & Mainly Asian ${ }^{\dagger}$ & Increased & 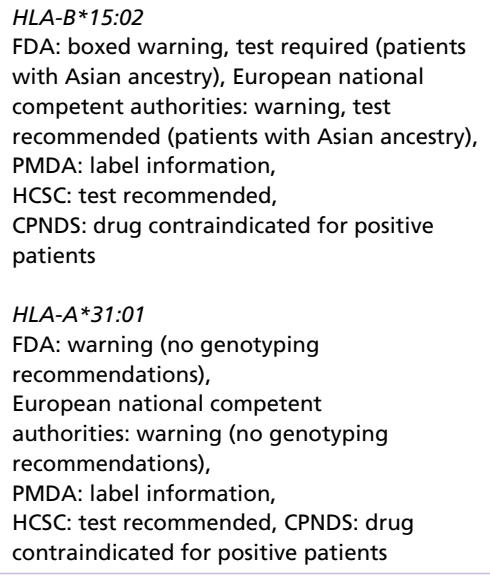 \\
\hline & $2 \mathrm{~A}$ & $H L A-B * 15: 11$ & SJS/TEN & $\begin{array}{l}\text { Asian (Japanese, } \\
\text { Korean, Han } \\
\text { Chinese) }\end{array}$ & Increased & \\
\hline & $2 \mathrm{~A}$ & $H L A-B * 40: 01$ & SJS/TEN & $\begin{array}{l}\text { Asian (Han } \\
\text { Chinese, } \\
\text { Taiwanese) }\end{array}$ & Decreased & \\
\hline & $2 \mathrm{~B}$ & $H L A-A * 31: 01$ & $\begin{array}{l}\text { DRESS, MPE, } \\
\text { SJS/TEN }\end{array}$ & $\begin{array}{l}\text { Mixed } \\
\text { population (see } \\
\text { text for further } \\
\text { details) }\end{array}$ & Increased & \\
\hline & $2 \mathrm{~B}$ & $\begin{array}{l}H L A-C^{*} 03: 02 \text { (in LD } \\
\text { with } H L A-B^{*} 58: 01 \text { in } \\
\text { some populations) }\end{array}$ & SJS/TEN & $\begin{array}{l}\text { Mixed } \\
\text { population }\end{array}$ & Increased & \\
\hline & 3 & $H L A-B * 15: 18$ & SJS/TEN & Asian (Japanese) & Increased & \\
\hline & 3 & $H L A-B * 58: 01$ & MEP & $\begin{array}{l}\text { Asian (Han } \\
\text { Chinese) }\end{array}$ & Decreased & \\
\hline & 3 & $H L A-B * 58: 01$ & SJS/TEN & $\begin{array}{l}\text { Asian (Han } \\
\text { Chinese) }\end{array}$ & $\begin{array}{l}\text { Increased } \\
\text { (decreased in one } \\
\text { study) }\end{array}$ & \\
\hline & 3 & $H L A-B * 59: 01$ & SJS/TEN & Asian (Japanese) & Increased & \\
\hline & 3 & $H L A-B * 13: 01$ & $\begin{array}{l}\text { Drug } \\
\text { hypersensitivity }\end{array}$ & Caucasian, Asian & $\begin{array}{l}\text { Increased (not in all } \\
\text { studies) }\end{array}$ & \\
\hline & 3 & $H L A-B * 46: 01$ & SJS/TEN & Asian & Decreased & \\
\hline & 3 & $H L A-B * 51: 01$ & $\begin{array}{l}\text { Drug } \\
\text { hypersensitivity }\end{array}$ & $\begin{array}{l}\text { Mixed } \\
\text { population }\end{array}$ & Increased & \\
\hline & 3 & $H L A-D R B 1 * 03: 01$ & MEP & $\begin{array}{l}\text { Asian (Han } \\
\text { Chinese) }\end{array}$ & Increased & \\
\hline \multicolumn{7}{|c|}{$\begin{array}{l}\text { †PharmGKB levels of evidence for clinical annotations. Levels of evidence vary from } 1 \text { (robust data, most important associations) to } 4 \text { (less-consistent associations). PharmGKB curators } \\
\text { periodically review the level of evidence of clinical annotations, therefore, the level of evidence may change over time as a result of additional studies performed. } \\
\text { ACR: American College of Rheumatology; ADR: Adverse drug reaction; CPIC: Clinical Pharmacogenetics Implementation Consortium; CPNDS: Canadian Pharmacogenomics Network } \\
\text { for Drug Safety; DILI: Drug-induced liver injury; DPWG: Dutch Pharmacogenetics Working Group; DRESS: Drug reaction with eosinophilia and systemic symptom; HCSC: Health Canada } \\
\text { (Santé Canada); MPE: Maculopapular eruption, N/A: Not applicable; PharmGKB: Pharmacogenomics Knowledge Base; PMDA: Pharmaceuticals and Medical Devices Agency - Japan; } \\
\text { SJS: Stevens-Johnson syndrome; TEN: Toxic epidermal necrolysis. }\end{array}$} \\
\hline
\end{tabular}


Table 1. Most significant pharmacogenomics associations between classical HLA allelic variants and drug hypersensitivity reactions (source Pharmacogenomics Knowledge Base database) (cont.).

\begin{tabular}{|c|c|c|c|c|c|c|}
\hline \multirow[t]{2}{*}{ Drug } & $\begin{array}{l}\text { PharmGKB } \\
\text { level of } \\
\text { evidence }^{\dagger}\end{array}$ & Allele-haplotype & $\begin{array}{l}\text { Clinical mani- } \\
\text { festation(s) }\end{array}$ & Population(s) & Risk of ADR & Clinical implementation \\
\hline & 3 & $H L A-A * 24: 02$ & DRESS, SJS/TEN & $\begin{array}{l}\text { Mixed } \\
\text { population }\end{array}$ & \multicolumn{2}{|l|}{ Increased } \\
\hline & 3 & $H L A-A * 11: 01$ & SJS/TEN & $\begin{array}{l}\text { Mixed } \\
\text { population }\end{array}$ & \multicolumn{2}{|l|}{ Increased } \\
\hline & 3 & $H L A-C^{*} 08: 01$ & SJS/TEN & White & \multicolumn{2}{|l|}{ Increased } \\
\hline Carbimazole & $2 \mathrm{~A}$ & $H L A-B * 38: 02: 01$ & Agranulocytosis & $\begin{array}{l}\text { Mixed } \\
\text { population }\end{array}$ & Increased & $\mathrm{N} / \mathrm{A}$ \\
\hline Clindamycin & 3 & $\begin{array}{l}H L A-B * 51: 01 \\
H L A-B * 15: 27\end{array}$ & $\begin{array}{l}\text { Cutaneous } \\
\text { adverse drug } \\
\text { reactions }\end{array}$ & $\begin{array}{l}\text { Asian (Han } \\
\text { Chinese) }\end{array}$ & \multicolumn{2}{|l|}{ Increased } \\
\hline Clozapine & 3 & $H L A-D R B 3 * 02: 02$ & Agranulocytosis & Caucasian & Increased & $\mathrm{N} / \mathrm{A}$ \\
\hline \multirow[t]{2}{*}{ Dapsone } & $2 \mathrm{~A}$ & $H L A-B * 13: 01$ & $\begin{array}{l}\text { Drug } \\
\text { hypersensitivity }\end{array}$ & Asian & Increased & $\mathrm{N} / \mathrm{A}$ \\
\hline & 3 & $H L A-A * 02: 01$ & $\begin{array}{l}\text { Drug } \\
\text { hypersensitivity }\end{array}$ & $\begin{array}{l}\text { Asian (Japanese, } \\
\text { Korean, Chinese) }\end{array}$ & $\begin{array}{l}\text { Increased } \\
\text { (decreased in one } \\
\text { study) }\end{array}$ & $\mathrm{N} / \mathrm{A}$ \\
\hline Flucloxacillin & 3 & $H L A-B * 57: 01$ & $\begin{array}{l}\text { Drug-induced } \\
\text { liver injury }\end{array}$ & Caucasian & Increased & $\mathrm{N} / \mathrm{A}$ \\
\hline Flupirtine & 3 & $\begin{array}{l}H L A-D R B 1 * 16: 01- \\
H L A-D Q B 1-* 05: 02 \\
\text { haplotype }\end{array}$ & $\begin{array}{l}\text { Drug-induced } \\
\text { liver injury }\end{array}$ & European & Increased & \\
\hline \multirow[t]{3}{*}{ IFN- $\beta$} & 3 & $H L A-B * 15: 01$ & $\begin{array}{l}\text { Reduced } \\
\text { response to } \\
\text { therapy }\end{array}$ & $\begin{array}{l}\text { Iranian (multiple } \\
\text { sclerosis) }\end{array}$ & $\mathrm{N} / \mathrm{A}$ & $\mathrm{N} / \mathrm{A}$ \\
\hline & 3 & $\begin{array}{l}\text { rs9272105 } \\
(H L A-D Q A 1)\end{array}$ & $\begin{array}{l}\text { Developing } \\
\text { neutralizing } \\
\text { anti-IFN- } \beta \\
\text { antibodies }\end{array}$ & $\begin{array}{l}\text { White (multiple } \\
\text { sclerosis) }\end{array}$ & \multicolumn{2}{|l|}{$\begin{array}{l}\text { AA genotypes have } \\
\text { a decreased risk } \\
\text { while AG and GG } \\
\text { genotypes have an } \\
\text { increased risk }\end{array}$} \\
\hline & 3 & $H L A-D R B 1 * 04$ & $\begin{array}{l}\text { Better response } \\
\text { to therapy }\end{array}$ & $\begin{array}{l}\text { Iranian (multiple } \\
\text { sclerosis) }\end{array}$ & $\mathrm{N} / \mathrm{A}$ & \\
\hline \multirow[t]{3}{*}{ Lamotrigine } & 3 & $H L A-B * 58: 01$ & SJS/TEN & $\begin{array}{l}\text { Mixed } \\
\text { population }\end{array}$ & Increased & $\mathrm{N} / \mathrm{A}$ \\
\hline & 3 & $H L A-B * 15: 02$ & SJS/TEN & Asian & \multicolumn{2}{|l|}{$\begin{array}{l}\text { Increased (only } \\
\text { found in } \\
\text { meta-analyses) }\end{array}$} \\
\hline & 3 & $H L A-B * 38: 01$ & SJS/TEN & White & \multicolumn{2}{|l|}{ Increased } \\
\hline \multirow[t]{2}{*}{ Lapatinib } & $2 \mathrm{~B}$ & $H L A-D Q A 1 * 02: 01$ & $\begin{array}{l}\text { Drug-induced } \\
\text { liver injury }\end{array}$ & $\begin{array}{l}\text { Mixed } \\
\text { population }\end{array}$ & Increased & $\begin{array}{l}\text { HLA-DQA } 1 * 02: 01 \text { or } H L A-D R B 1 * 07: 01 \text { alleles } \\
\text { carrier FDA, EMA, PMDA and HCSC: warning } \\
\text { (no genotyping recommendations) }\end{array}$ \\
\hline & 3 & $H L A-D R B 1 * 07: 01$ & $\begin{array}{l}\text { Drug-induced } \\
\text { liver injury }\end{array}$ & $\begin{array}{l}\text { Mixed } \\
\text { population }\end{array}$ & \multicolumn{2}{|l|}{ Increased } \\
\hline Lumiracoxib & $\mathrm{N} / \mathrm{A}$ & $\begin{array}{l}H L A-D R B 1 * 1501- \\
H L A-D Q B 1 * 0602- \\
H L A-D R B 5 * 0101- \\
H L A-D Q A 1 * 0102 \\
\text { haplotype }\end{array}$ & $\begin{array}{l}\text { Drug-induced } \\
\text { liver injury }\end{array}$ & $\begin{array}{l}\text { Mixed } \\
\text { population }\end{array}$ & Increased & $\begin{array}{l}\text { Withdrawn from the market or not approved } \\
\text { following cases of hepatotoxicity in } 2007\end{array}$ \\
\hline \multirow[t]{2}{*}{ Methazolamide } & $2 \mathrm{~A}$ & $H L A-B * 59: 01$ & SJS/TEN & $\begin{array}{l}\text { Asian (Korean, } \\
\text { Japanese, } \\
\text { Chinese) }\end{array}$ & Increased & $\mathrm{N} / \mathrm{A}$ \\
\hline & $2 \mathrm{~B}$ & $H L A-C * 01: 02$ & SJS/TEN & $\begin{array}{l}\text { Asian (Korean, } \\
\text { Chinese) }\end{array}$ & \multicolumn{2}{|l|}{ Increased } \\
\hline \multicolumn{7}{|c|}{$\begin{array}{l}\text { †PharmGKB levels of evidence for clinical annotations. Levels of evidence vary from } 1 \text { (robust data, most important associations) to } 4 \text { (less-consistent associations). PharmGKB curators } \\
\text { periodically review the level of evidence of clinical annotations, therefore, the level of evidence may change over time as a result of additional studies performed. } \\
\text { ACR: American College of Rheumatology; ADR: Adverse drug reaction; CPIC: Clinical Pharmacogenetics Implementation Consortium; CPNDS: Canadian Pharmacogenomics Network } \\
\text { for Drug Safety; DILI: Drug-induced liver injury; DPWG: Dutch Pharmacogenetics Working Group; DRESS: Drug reaction with eosinophilia and systemic symptom; HCSC: Health Canada } \\
\text { (Santé Canada); MPE: Maculopapular eruption, N/A: Not applicable; PharmGKB: Pharmacogenomics Knowledge Base; PMDA: Pharmaceuticals and Medical Devices Agency - Japan; } \\
\text { SJS: Stevens-Johnson syndrome; TEN: Toxic epidermal necrolysis. }\end{array}$} \\
\hline
\end{tabular}


Table 1. Most significant pharmacogenomics associations between classical HLA allelic variants and drug hypersensitivity reactions (source Pharmacogenomics Knowledge Base database) (cont.).

\begin{tabular}{|c|c|c|c|c|c|c|}
\hline Drug & $\begin{array}{l}\text { PharmGKB } \\
\text { level of } \\
\text { evidence }^{\dagger}\end{array}$ & Allele-haplotype & $\begin{array}{l}\text { Clinical mani- } \\
\text { festation(s) }\end{array}$ & Population(s) & Risk of ADR & Clinical implementation \\
\hline Methotrexate & 3 & $H L A-C * 06: 02$ & Better response & Tamil (psoriasis) & $\mathrm{N} / \mathrm{A}$ & $\mathrm{N} / \mathrm{A}$ \\
\hline Minocycline & 3 & $H L A-B * 35: 05$ & $\begin{array}{l}\text { Drug-induced } \\
\text { liver injury }\end{array}$ & White & Increased & $\mathrm{N} / \mathrm{A}$ \\
\hline \multirow[t]{5}{*}{ Nevirapine } & $2 \mathrm{~A}$ & $H L A-B * 35: 01$ & $\begin{array}{l}\text { Drug } \\
\text { hypersensitivity } \\
\text { (rash) }\end{array}$ & $\begin{array}{l}\text { Mixed } \\
\text { population }\end{array}$ & Increased & $\mathrm{N} / \mathrm{A}$ \\
\hline & $2 \mathrm{~B}$ & $H L A-D R B 1 * 01: 01$ & $\begin{array}{l}\text { Drug } \\
\text { hypersensitivity } \\
\text { (hepatitis, } \\
\text { systemic } \\
\text { symptoms, rash) }\end{array}$ & $\begin{array}{l}\text { Mixed } \\
\text { population }\end{array}$ & $\begin{array}{l}\text { Increased (all } \\
\text { manifestations, but } \\
\text { not rash, reported } \\
\text { to be dependent on } \\
\text { CD4 }{ }^{+} \text {T-cell count) }\end{array}$ & \\
\hline & 3 & $H L A-D Q B 1 * 05: 01$ & $\begin{array}{l}\text { Drug } \\
\text { hypersensitivity } \\
\text { (various } \\
\text { manifestation) }\end{array}$ & $\begin{array}{l}\text { Black or African } \\
\text { American }\end{array}$ & Decreased & \\
\hline & 3 & $H L A-B * 35: 05$ & Skin rash & Asian (Thai) & Increased & \\
\hline & 3 & rs9461684 (HLA-C) & Skin rash & Asian & $\begin{array}{l}\text { CC and CT } \\
\text { genotypes have a } \\
\text { decreased risk while } \\
\text { TT genotype have } \\
\text { an increased risk }\end{array}$ & \\
\hline $\begin{array}{l}\text { Nonsteroidal Anti- } \\
\text { Inflammatory } \\
\text { Drugs }\end{array}$ & 3 & $H L A-D R B 1 * 11: 01$ & $\begin{array}{l}\text { Anaphylactic } \\
\text { reactions }\end{array}$ & White & Increased & $\mathrm{N} / \mathrm{A}$ \\
\hline \multirow[t]{5}{*}{ Oxcarbazepine } & 3 & $H L A-B * 13: 02$ & MEP & Asian (Chinese) & Increased & $\begin{array}{l}H L A-B * 15: 02 \\
\text { FDA: warning, test recommended in genetically } \\
\text { at-risk populations }\end{array}$ \\
\hline & 3 & $H L A-B * 15: 02$ & MEP, SJS/TEN & Asian & Increased & \\
\hline & 3 & $\begin{array}{l}H L A-B * 15: 19 ; H L A-B \\
* 15: 27 ; H L A-B * 27: 09 ; \\
H L A-B * 38: 02 ; H L A-B \\
* 48: 04\end{array}$ & MEP & $\begin{array}{l}\text { Asian (Han } \\
\text { Chinese) }\end{array}$ & Increased & \\
\hline & 3 & $\begin{array}{l}H L A-B * 40: 02 \\
H L A-B * 15: 01 \\
H L A-D R B 1 * 04: 03\end{array}$ & MEP & Korean & Increased & $\mathrm{N} / \mathrm{A}$ \\
\hline & 4 & $\begin{array}{l}\text { HLA- } \\
B * 15: 18: 01 / * 40: 01: 01 \\
\text { genotype }\end{array}$ & SJS/TEN & $\begin{array}{l}\text { Mixed } \\
\text { population }\end{array}$ & Increased & $\mathrm{N} / \mathrm{A}$ \\
\hline Pazopanib & $\mathrm{N} / \mathrm{A}$ & $H L A-B * 57: 01$ & DILI & $\begin{array}{l}\text { Mixed } \\
\text { population }\end{array}$ & Increased & FDA: label annotation \\
\hline \multirow[t]{2}{*}{$\begin{array}{l}\text { Pegylated } \\
\text { interferon and } \\
\text { ribavirin }\end{array}$} & 3 & $H L A-B * 38: 01$ & $\begin{array}{l}\text { Nonresponder } \\
\text { to therapy }\end{array}$ & $\begin{array}{l}\text { Egyptian } \\
\text { (hepatitis C) }\end{array}$ & $\mathrm{N} / \mathrm{A}$ & $\begin{array}{l}\text { DPWG: information about lower response in } \\
H L A-B * 44 \text {-negative patients (no genotyping } \\
\text { recommendations) }\end{array}$ \\
\hline & 3 & $H L A-B * 44: 02$ & $\begin{array}{l}\text { Sustained } \\
\text { response (C } \\
\text { Hepatitis) }\end{array}$ & Spain & $\mathrm{N} / \mathrm{A}$ & \\
\hline $\begin{array}{l}\text { Pegylated } \\
\text { interferon alfa-2b } \\
\text { (with or without } \\
\text { entecavir) }\end{array}$ & 3 & rs3077 (HLA-DPA1) & $\begin{array}{l}\text { AA and AG } \\
\text { genotype have } \\
\text { poorer } \\
\text { response while } \\
\text { GG genotypes } \\
\text { have better } \\
\text { response }\end{array}$ & Thai (hepatitis B) & $\mathrm{N} / \mathrm{A}$ & $\mathrm{N} / \mathrm{A}$ \\
\hline \multicolumn{7}{|c|}{$\begin{array}{l}\text { †PharmGKB levels of evidence for clinical annotations. Levels of evidence vary from } 1 \text { (robust data, most important associations) to } 4 \text { (less-consistent associations). PharmGKB curators } \\
\text { periodically review the level of evidence of clinical annotations, therefore, the level of evidence may change over time as a result of additional studies performed. } \\
\text { ACR: American College of Rheumatology; ADR: Adverse drug reaction; CPIC: Clinical Pharmacogenetics Implementation Consortium; CPNDS: Canadian Pharmacogenomics Network } \\
\text { for Drug Safety; DILI: Drug-induced liver injury; DPWG: Dutch Pharmacogenetics Working Group; DRESS: Drug reaction with eosinophilia and systemic symptom; HCSC: Health Canada } \\
\text { (Santé Canada); MPE: Maculopapular eruption, N/A: Not applicable; PharmGKB: Pharmacogenomics Knowledge Base; PMDA: Pharmaceuticals and Medical Devices Agency - Japan; } \\
\text { SJS: Stevens-Johnson syndrome; TEN: Toxic epidermal necrolysis. }\end{array}$} \\
\hline
\end{tabular}


Table 1. Most significant pharmacogenomics associations between classical HLA allelic variants and drug hypersensitivity reactions (source Pharmacogenomics Knowledge Base database) (cont.).

\begin{tabular}{|c|c|c|c|c|c|c|}
\hline Drug & $\begin{array}{l}\text { PharmGKB } \\
\text { level of } \\
\text { evidence }^{\dagger}\end{array}$ & Allele-haplotype & $\begin{array}{l}\text { Clinical mani- } \\
\text { festation(s) }\end{array}$ & Population(s) & Risk of ADR & Clinical implementation \\
\hline Phenobarbital & 3 & $H L A-B * 51: 01$ & SJS/TEN & Asian & Increased & $\mathrm{N} / \mathrm{A}$ \\
\hline \multirow[t]{4}{*}{ Phenytoin } & $1 \mathrm{~A}$ & $H L A-B * 15: 02$ & SJS/TEN & Asian & Increased & $\begin{array}{l}B * 15: 02 \\
\text { FDA: warning (avoid drug in positive patients), } \\
\text { CPIC: drug contraindicated for positive patients, } \\
\text { HCSC: test recommended }\end{array}$ \\
\hline & 3 & $H L A-B * 13: 01$ & SJS/TEN & Asian & $\begin{array}{l}\text { Increased (not } \\
\text { increased in one } \\
\text { study) }\end{array}$ & \\
\hline & 3 & $H L A-C * 08: 01$ & MPE, SJS/TEN & $\begin{array}{l}\text { Mixed } \\
\text { population }\end{array}$ & & \\
\hline & 4 & $H L A-B * 56: 02$ & DRESS & $\begin{array}{l}\text { Indigenous } \\
\text { Australian }\end{array}$ & Increased & \\
\hline $\begin{array}{l}\text { Statins } \\
\text { (atorvastatin, } \\
\text { fluvastatin, } \\
\text { pitavastatin, } \\
\text { pravastatin, } \\
\text { rosuvastatin or } \\
\text { simvastatin) }\end{array}$ & 3 & $H L A-D R B 1$ variants & $\begin{array}{l}\text { Statin-related } \\
\text { myopathy }\end{array}$ & Japanese & $\begin{array}{l}\text { HLA-DRB1 } * 04: 06 \text { is } \\
\text { associated with } \\
\text { increased risk as } \\
\text { compared with } \\
\text { HLA-DRB1 } * 01: 01\end{array}$ & $\mathrm{~N} / \mathrm{A}$ \\
\hline \multirow[t]{2}{*}{ Sulfasalazine } & 3 & $\begin{array}{l}H L A-B * 39: 01 ; H L A-B \\
* 13: 01\end{array}$ & DRESS & Asian & Increased & $\mathrm{N} / \mathrm{A}$ \\
\hline & 4 & $H L A-B * 15: 05$ & DRESS & Asian & Increased & \\
\hline $\begin{array}{l}\text { Thioamides } \\
\text { (carbimazole, } \\
\text { methimazole, } \\
\text { propylthiouracil) }\end{array}$ & $2 \mathrm{~A}$ & $H L A-B * 38: 02: 01$ & Agranulocytosis & $\begin{array}{l}\text { Mixed } \\
\text { population }\end{array}$ & Increased & $\mathrm{N} / \mathrm{A}$ \\
\hline \multirow[t]{2}{*}{ Ticlopidine } & 3 & $H L A-B * 44: 03$ & $\begin{array}{l}\text { Drug-induced } \\
\text { liver injury }\end{array}$ & Asian & Increased & $\mathrm{N} / \mathrm{A}$ \\
\hline & 3 & $H L A-C * 14: 03$ & $\begin{array}{l}\text { Drug-induced } \\
\text { liver injury }\end{array}$ & Asian & Increased & \\
\hline Trichloroethylene & 3 & $H L A-B * 13: 01$ & $\begin{array}{l}\text { Hypersensitivity } \\
\text { dermatitis }\end{array}$ & Asian (Chinese) & Increased & $\mathrm{N} / \mathrm{A}$ \\
\hline TNF- $\alpha$ inhibitors & 3 & rs12191877 (HLA-C) & $\begin{array}{l}\text { CC genotypes } \\
\text { have poorer } \\
\text { response while } \\
\text { CT and CT } \\
\text { genotypes have } \\
\text { better response }\end{array}$ & White (psoriasis) & $\mathrm{N} / \mathrm{A}$ & $\mathrm{N} / \mathrm{A}$ \\
\hline Ustekinumab & 3 & $H L A-C * 06: 02$ & Better response & $\begin{array}{l}\text { Caucasian } \\
\text { (psoriasis) }\end{array}$ & $\mathrm{N} / \mathrm{A}$ & $\mathrm{N} / \mathrm{A}$ \\
\hline Ximelagatran & $\mathrm{N} / \mathrm{A}$ & $\begin{array}{l}D R B 1 * 07: 01 \\
D Q A 1 * 02: 01\end{array}$ & $\begin{array}{l}\text { Drug-induced } \\
\text { liver injury }\end{array}$ & European & Increased & $\begin{array}{l}\text { Withdrawn from the market in } 2006 \text { following } \\
\text { reports of hepatotoxicity }\end{array}$ \\
\hline Zonisamide & 3 & $H L A-A * 02: 07: 01$ & SJS/TEN & Asian (Japanese) & Increased & $\mathrm{N} / \mathrm{A}$ \\
\hline \multicolumn{7}{|c|}{$\begin{array}{l}\text { †PharmGKB levels of evidence for clinical annotations. Levels of evidence vary from } 1 \text { (robust data, most important associations) to } 4 \text { (less-consistent associations). PharmGKB curators } \\
\text { periodically review the level of evidence of clinical annotations, therefore, the level of evidence may change over time as a result of additional studies performed. } \\
\text { ACR: American College of Rheumatology; ADR: Adverse drug reaction; CPIC: Clinical Pharmacogenetics Implementation Consortium; CPNDS: Canadian Pharmacogenomics Network } \\
\text { for Drug Safety; DILI: Drug-induced liver injury; DPWG: Dutch Pharmacogenetics Working Group; DRESS: Drug reaction with eosinophilia and systemic symptom; HCSC: Health Canada } \\
\text { (Santé Canada); MPE: Maculopapular eruption, N/A: Not applicable; PharmGKB: Pharmacogenomics Knowledge Base; PMDA: Pharmaceuticals and Medical Devices Agency - Japan; } \\
\text { SJS: Stevens-Johnson syndrome; TEN: Toxic epidermal necrolysis. }\end{array}$} \\
\hline
\end{tabular}

population and the number of patients needed to test in order to prevent a case is low. Furthermore, the drug for which genetic test is postulated, should have good efficacy, cost-effectiveness and tolerability, in the absence of alternative therapies with comparable positive features [57].

From the examples of HLA-HDR-drug associations discussed above, it emerges clearly that certain individuals positive for a susceptibility HLA allele do not develop hypersensitivity if exposed to the culprit drug. This notion implies two major considerations, largely generalizable to other HLA-associated HDRs. First, a particular HLA allotype is necessary (high NPV) but not sufficient (low PPV) for disease to occur, and additional genetic 
Table 2. Additional risk factors, other than HLA, involved in drug hypersensitivity (not exhaustive listing).

\begin{tabular}{|c|c|}
\hline Risk factors & Examples and comments \\
\hline Concomitant virus reactivation or infections & HIV and herpes viruses \\
\hline Factors that influence drug levels (environmental and genetic) & $\begin{array}{l}\text { Dosage and chronic renal insufficiency in allopurinol-induced HDRs, synergistic } \\
\text { effect of } H L A-A * 33: 03 \text { and gain-of-function variants in CYP2B6 on } \\
\text { ticlopidine-induced DILI, HLA-DRw4 and slow acetylator phenotype in } \\
\text { hydralazine-induced Systemic Lupus Erythematosus }\end{array}$ \\
\hline Female sex & $\begin{array}{l}\text { Immune-related diseases are more common in women (e.g., autoimmune disorders) } \\
\text { but influence of sex on HDRs is not clearly defined }\end{array}$ \\
\hline Genes involved in cytokine production & $\begin{array}{l}\text { TNF-alpha promoter polymorphism and } H L A D P B 1 * 0301 \text { in aspirin-induced asthma, } \\
\text { or HLA-DR3 and }-D Q 2 \text { in carbamazepine-related } H D R\end{array}$ \\
\hline Immune status of patients & CD4 T-cell counts and nevirapine HDR, CD8 ${ }^{+} \mathrm{T}$-cell counts in abacavir HDR \\
\hline Intrinsic immunogenicity of the drug & $\begin{array}{l}\text { Structurally related aromatic anticonvulsants may induce HDRs (e.g., } H L A-B * 15: 02 \\
\text { and HDRs related to various aromatic antiepileptic drugs) }\end{array}$ \\
\hline Race, ethnicity & $\begin{array}{l}\text { Frequency of a given HLA allotype differs across populations, but other, still } \\
\text { unknown, factors may be involved }\end{array}$ \\
\hline T-cell receptor repertoires & $\begin{array}{l}H L A-B * 15: 02 \text { and } V B-11-I S G S Y T C R \text { clonotype may synergically contribute to } \\
\text { carbamazepine-related HDR }\end{array}$ \\
\hline
\end{tabular}

and/or environmental causal factors should be at play (Table 2) [91,92]. Unfortunately, the characterization of these contributing factors is still largely incomplete, and there is a need of further research on this topic. Accordingly, HLA typing should be accompanied by the analysis of additional individual's characteristics and risk factors in order to better delineate patients with an increased risk of a particular hypersensitivity, thus improving the efficacy/predictivity of the screening. Second, it is clear that, although on the one hand HLA screening reduce the risk of hypersensitivity, on the other hand it may deny optimal treatment to individuals who could tolerate the drug and oblige the clinician to prescribe less efficient and/or more expensive alternative therapies.

In view of all these premises, only few HLA hypersensitivity drug associations reported so far will be translated into clinical routine as pretreatment screening tests. Nevertheless, beside the prospective use of genotyping to predict and prevent ADRs, pharmacogenetic tests can also be exploited for clinical diagnosis. In this context, the genetic test is performed at the time of the ADR in exposed patients rather than prior to drug prescription. Flucloxacillin-induced cholestatic hepatitis is strongly associated with the presence of $H L A-B^{*} 57: 01$ allele (OR $108)$, but due to its extremely low prevalence ( 8.5 cases $/ 100,000$ treated patients), it has been estimated that 13,500 subjects would need to be screened to prevent one case of HDR. As a consequence, pre-administration testing would not be cost-effectively applicable in clinical routine [40,93-95]. However, the very-high NPV (almost $100 \%$ ) suggests a role of $H L A-B^{*} 57: 01$ genotyping as differential diagnosis tools in patients exposed to flucloxacillin presenting an acute liver disease in order to exclude drug-related hepatitis. The usage of genetic test for diagnostic purpose would be potentially applicable for other drug-induced liver injury in which NPV of nearly $100 \%$ would permit to effectively rule out the drug as putative cause for liver toxicity. Examples include, but are not limited to: amoxicillin-clavulanic acid $\left(H L A-D R B 1^{*} 15: 01\right)$ and lapatinib $\left(D R B 1^{*} 07: 01\right.$ and $\left.D Q A 1^{*} 02: 01\right)$ [88]. Because serious HDRs are very rare, they are seldom detected during preclinical testing (animal models) or clinical trials, and, in the majority of cases, they are identified during postmarketing when a large number of patients have been treated. This often results in the drug's withdrawal from the market. As a consequence, HDRs represent a major cost burden for pharmaceutical industry contributing to the elevated costs of drug development. A systematic DNA banking during drug development could allow, if an HDR occurs, to retrospectively identify a susceptibility genomic biomarker. The availability of predictive marker could avoid market withdrawal by individualizing the use of the drug to genetically tolerant individuals [96].

The notion that some HDRs are related to specific HLA alleles and can be prevented by prospective pharmacogenomics testing, has made HDRs (at least some of them) preventable thus breaking the dogma of their unpredictability. Currently, a huge number of HLA-related HDRs has been described, but there are still many hurdles to overcome before these associations could be translated into the clinical practice, and only few of them have been successfully implemented so far. Thus, it is clear that there is a great potential for pharmacogenomics of HLA to improve the tolerability profile of drugs, but, at the same time, there is also the need for further research. In this scenery, efforts should be made in order to improve both multidisciplinary basic and clinical research, going from bench to bedside and then back, from bedside back to bench. Basic research could add important insights 
to the immunopathogenic mechanisms of these syndromes, allow the development of diagnostic tests and improve drug design by predicting immunogenicity of a given compound at the preclinical stage of its development. On the other hand, the qualitative and quantitative improvement of the clinical research protocols (e.g., prospective clinical trials, collaborative consortia and international registries) may help to define the real clinical validity and cost-effectiveness of a given association, providing more robust bases for its translation into the routine clinical practice.

Before concluding this review focused on immune-mediated ADRs, mention ought to be made of adverse events related to checkpoint inhibitor agents. Immune checkpoint inhibitors are drugs, typically monoclonal antibodies, which block specific molecules (immune checkpoints) that negatively regulate the immune response. Physiologically, these inhibitory pathways serve to 'switch off' the immune response when it is no longer required in order to prevent tissue injury and autoimmunity. Therefore, immune checkpoint blockade 'by inhibiting the inhibition of the immune response' unleash the immune system against cancer cells [97].

Overall, immune checkpoint inhibitors are well-tolerated drugs, particularly when compared with standard cytotoxic agents, nevertheless they can induce a broad spectrum of immune-related toxicities [98]. Immune-related ADRs triggered by immune checkpoint inhibitors can affect virtually every organ system (e.g., skin, GI tract, endocrine system, liver, etc.) and can be extremely debilitating and potentially life threatening [98]. Although the precise pathophysiologic mechanisms responsible for these ADRs are not completely understood, they are commonly considered to be dependent on the overactivation of the immune system resulting in autoimmune reactions [98100]. Accordingly, immune-related ADRs induced by checkpoint inhibitors are ascribable to the pharmacologic (immunostimulatory) properties of the drug, and are therefore classifiable as type A ADRs sensu stricto [100].

To the best of our knowledge, no associations between ADRs triggered by checkpoint inhibitors and specific HLA alleles (or haplotypes) have been reported to date in the literature, nevertheless this topic represents an extremely interesting field which deserves to be explored in the future.

Financial \& competing interests disclosure

L Becquemont is affiliated with/has received financial support from Antisens Therapeutics, Alnylam Pharmaceuticals, PregLem SA, ISIS Pharmaceutical, Novartis Pharma, Auris Medical, Medday Pharmaceuticals, Gilead, Sanofi-Aventis, Pfizer, Servier, Genzyme, GlaxoSmithKline, Bristol-Myers Squibb, Merck Sharp and Dohme. S Negrini has nothing to disclose. The authors have no other relevant affiliations or financial involvement with any organization or entity with a financial interest in or financial conflict with the subject matter or materials discussed in the manuscript apart from those disclosed.

No writing assistance was utilized in the production of this manuscript.

\section{Executive summary}

- Pharmacogenomics studies the genetic bases of drug efficacy and toxicity in order to optimize drug prescription practice thus contributing to the so-called tailored, or personalized medicine.

- A growing number of studies have demonstrated strong associations between specific HLA alleles and susceptibility to develop delayed drug hypersensitivity reactions.

- Different models have been proposed to explain how drugs, generally too small to be immunogenic, can activate $T$ cells. These, nonmutually exclusive theories are: the 'hapten/prohapten model', the 'pharmacologic interaction ( $p$-i) with immune receptors concept' and the 'altered peptide repertoire hypothesis'.

- Despite the huge number of HLA-related hypersensitivity drug reactions (HDRs) described so far, only very few pharmacogenomics screening tests have been successfully translated into routine clinical practice.

- HLA-drug-HDR associations that have more robust pharmacogenetic data include abacavir hypersensitivity syndrome $(H L A-B * 57: 01)$ and severe cutaneous reactions induced by carbamazepine and allopurinol ( $H L A-B * 15: 02$ and $H L A B * 58: 01$, respectively).

- HLA pharmacogenomics has demonstrated that 'unpredictable' HDRs, at least for some compounds, could be prevented by genetic testing.

\section{References}

Papers of special note have been highlighted as: $\bullet$ of interest; $\bullet \bullet$ of considerable interest

1. Chan SL, Ang X, Sani LL et al. Prevalence and characteristics of adverse drug reactions at admission to hospital: a prospective observational study. Br. J. Clin. Pharmacol. 82(6), 1636-1646 (2016).

2. International drug monitoring: the role of national centres. Report of a WHO meeting. WHO Tech. Rep. Ser. 498, 1-25 (1972). 
3. Lazarou J, Pomeranz BH, Corey PN. Incidence of adverse drug reactions in hospitalized patients: a meta-analysis of prospective studies. JAMA 279(15), 1200-1205 (1998).

4. The European Commission document "Strengthening pharmacovigilance to reduce adverse effects of medicines. (2008). http://europa.eu/rapid/press-release_MEMO-08-782_en.htm?locale=en

5. Ernst FR, Grizzle AJ. Drug-related morbidity and mortality: updating the cost-of-illness model. J. Am. Pharm. Assoc. (Wash.) 41(2), 192-199 (2001).

6. Wysowski DK, Swartz L. Adverse drug event surveillance and drug withdrawals in the United States, 1969-2002: the importance of reporting suspected reactions. Arch. Intern. Med. 165(12), 1363-1369 (2005).

7. Rawlins MD, Thompson JW. Pathogenesis of adverse drug reactions. In: Textbook of Adverse Drug Reactions. Oxford University Press, Oxford, UK (1977).

8. Pichler WJ, Hausmann O. Classification of drug hypersensitivity into allergic, p-i, and pseudo-allergic forms. Int. Arch. Allergy Immunol. 171(3-4), 166-179 (2016).

- A very comprehensive review on the immunopathogenic mechanisms involved in drug-induced hypersensitivity reactions.

9. Johansson SG, Bieber T, Dahl R et al. Revised nomenclature for allergy for global use: report of The Nomenclature Review Committee of the World Allergy Organization, October 2003. J. Allergy Clin. Immunol. 113(5), 832-836 (2004).

- Statement paper of the World Allergy Organization for the standardization of the nomenclature of allergic diseases, also including drug-related hypersensitivities.

10. Barbarino JM, Kroetz DL, Klein TE, Altman RB. PharmGKB summary: very important pharmacogene information for human leukocyte antigen B. Pharmacogenet. Genomics 25(4), 205-221 (2015).

11. Choo SY. The HLA system: genetics, immunology, clinical testing, and clinical implications. Yonsei Med. J. 48(1), 11-23 (2007).

12. Blackwell JM, Jamieson SE, Burgner D. HLA and infectious diseases. Clin. Microbiol. Rev. 22(2), 370-385, (2009).

13. Gough SC, Simmonds MJ. The HLA region and autoimmune disease: associations and mechanisms of action. Curr. Genomics 8(7), 453-465 (2007).

14. Illing PT, Mifsud NA, Purcell AW. Allotype specific interactions of drugs and HLA molecules in hypersensitivity reactions. Curr. Opin. Immunol. 42, 31-40 (2016).

15. Pichler WJ, Adam J, Daubner B, Gentinetta T, Keller M, Yerly D. Drug hypersensitivity reactions: pathomechanism and clinical symptoms. Med. Clin. North Am. 94(4), 645-664 (2010).

16. Schnyder B, Mauri-Hellweg D, Zanni M, Bettens F, Pichler WJ. Direct, MHC-dependent presentation of the drug sulfamethoxazole to human alphabeta T-cell clones. J. Clin. Invest. 100(1), 136-141 (1997).

17. Naisbitt DJ, Farrell J, Wong G et al. Characterization of drug-specific T cells in lamotrigine hypersensitivity. J. Allergy Clin. Immunol. 111(6), 1393-1403 (2003).

18. Zanni MP, Von Greyerz S, Schnyder B et al. HLA-restricted, processing- and metabolism-independent pathway of drug recognition by human alpha beta T lymphocytes. J. Clin. Invest. 102(8), 1591-1598 (1998).

19. Pavlos R, Mallal S, Ostrov D, Pompeu Y, Phillips E. Fever, rash, and systemic symptoms: understanding the role of virus and HLA in severe cutaneous drug allergy. J. Allergy Clin. Immunol. Pract. 2(1), 21-33 (2014).

20. Hetherington S, Mcguirk S, Powell G et al. Hypersensitivity reactions during therapy with the nucleoside reverse transcriptase inhibitor abacavir. Clin. Ther. 23(10), 1603-1614 (2001).

21. Chaponda M, Pirmohamed M. Hypersensitivity reactions to HIV therapy. Br. J. Clin. Pharmacol. 71(5), 659-671 (2011).

22. Hetherington $S$, Hughes AR, Mosteller M et al. Genetic variations in HLA-B region and hypersensitivity reactions to abacavir. Lancet 359(9312), 1121-1122 (2002).

- Description of the association between HLA-B in situ 5701 and abacavir hypersensitivity syndrome.

23. Mallal S, Nolan D, Witt C et al. Association between presence of HLA-B in situ 5701, HLA-DR7, and HLA-DQ3 and hypersensitivity to HIV-1 reverse-transcriptase inhibitor abacavir. Lancet 359(9308), 727-732 (2002).

- Description of the association between HLA-B in situ 5701 and abacavir hypersensitivity syndrome.

24. Hughes DA, Vilar FJ, Ward CC, Alfirevic A, Park BK, Pirmohamed M. Cost-effectiveness analysis of HLA B in situ 5701 genotyping in preventing abacavir hypersensitivity. Pharmacogenetics 14(6), 335-342 (2004).

25. Rauch A, Nolan D, Martin A, Mckinnon E, Almeida C, Mallal S. Prospective genetic screening decreases the incidence of abacavir hypersensitivity reactions in the Western Australian HIV cohort study. Clin. Infect. Dis. 43(1), 99-102 (2006).

26. Waters LJ, Mandalia S, Gazzard B, Nelson M. Prospective HLA-B in situ 5701 screening and abacavir hypersensitivity: a single centre experience. AIDS 21(18), 2533-2534 (2007).

27. Zucman D, Truchis P, Majerholc C, Stegman S, Caillat-Zucman S. Prospective screening for human leukocyte antigen-B in situ 5701 avoids abacavir hypersensitivity reaction in the ethnically mixed French HIV population. J. Acquir. Immune Defic. Syndr. 45(1), 1-3 (2007). 
28. Mallal S, Phillips E, Carosi G et al. HLA-B in situ 5701 screening for hypersensitivity to abacavir. N. Engl. J. Med. 358(6), 568-579 (2008).

- Seminal pharmacogenetic trial demonstrating the validity of the HLA-B in situ 57:01 screening.

29. Saag M, Balu R, Phillips E et al. High sensitivity of human leukocyte antigen-b in situ 5701 as a marker for immunologically confirmed abacavir hypersensitivity in white and black patients. Clin. Infect. Dis. 46(7), 1111-1118 (2008).

- Case-control study in white and black Americans confirming the value of the HLA-B in situ 57:01 screening across different races.

30. Sousa-Pinto B, Pinto-Ramos J, Correia C et al. Pharmacogenetics of abacavir hypersensitivity: a systematic review and meta-analysis of the association with HLA-B in situ 57:01. J. Allergy Clin. Immunol. 136(4), 1092-1094.e3 (2015).

31. EMA. European Medicines Agency. www.ema.europa.eu

32. FDA. US Food and Drug Administration. www.fda.gov

33. Zucman D, Truchis P, Majerholc C, Stegman S, Caillat-Zucman S. Prospective screening for human leukocyte antigen-B in situ 5701 avoids abacavir hypersensitivity reaction in the ethnically mixed French HIV population. J. Acquir. Immune Defic. Syndr. 45(1), 1-3 (2007).

34. Small CB, Margolis DA, Shaefer MS, Ross LL. HLA-B in situ 57:01 allele prevalence in HIV-infected North American subjects and the impact of allele testing on the incidence of abacavir-associated hypersensitivity reaction in HLA-B in situ 57:01 negative subjects. BMC Infect. Dis. 17(1), 256 (2017).

35. Ruiz-Iruela C, Padulles-Zamora N, Podzamczer-Palter D et al. HLA-B in situ 57:01 genotyping in the prevention of hypersensitivity to abacavir: 5 years of experience. Pharmacogenet. Genomics 26(8), 390-396 (2016).

36. Nieves Calatrava D, Calle-Martin Ode L, Iribarren-Loyarte JA et al. Cost-effectiveness analysis of HLA-B in situ 5701 typing in the prevention of hypersensitivity to abacavir in HIV+ patients in Spain. Enferm. Infecc. Microbiol. Clin. 28(9), 590-595 (2010).

37. Chessman D, Kostenko L, Lethborg $\mathrm{T}$ et al. Human leukocyte antigen class I-restricted activation of $\mathrm{CD} 8^{+} \mathrm{T}$ cells provides the immunogenetic basis of a systemic drug hypersensitivity. Immunity 28(6), 822-832 (2008).

38. Petros Z, Kishikawa J, Makonnen E, Yimer G, Habtewold A, Aklillu E. HLA-B* 57 allele is associated with concomitant anti-tuberculosis and antiretroviral drugs induced liver toxicity in Ethiopians. Front. Pharmacol. 8, 90 (2017).

39. Xu CF, Johnson T, Wang X et al. HLA-B in situ 57:01 confers susceptibility to pazopanib-associated liver injury in patients with cancer. Clin. Cancer Res. 22(6), 1371-1377 (2016).

40. Daly AK, Donaldson PT, Bhatnagar P et al. HLA-B in situ 5701 genotype is a major determinant of drug-induced liver injury due to flucloxacillin. Nat. Genet. 41(7), 816-819 (2009).

- Genome-wide association study demonstrating the strong association between HLA-B in situ 5701 and flucloxacillin-induced liver injury.

41. Mockenhaupt M. The current understanding of Stevens-Johnson syndrome and toxic epidermal necrolysis. Expert Rev. Clin. Immunol. 7(6), 803-813; quiz 814-805 (2011).

42. Harr T, French LE. Toxic epidermal necrolysis and Stevens-Johnson syndrome. Orphanet J. Rare Dis. 5, 39 (2010).

43. Kang HR, Jee YK, Kim YS et al. Positive and negative associations of HLA class I alleles with allopurinol-induced SCARs in Koreans. Pharmacogenet. Genomics 21(5), 303-307 (2011).

44. Sousa-Pinto B, Correia C, Gomes L et al. HLA and delayed drug-induced hypersensitivity. Int. Arch. Allergy Immunol. 170(3), 163-179 (2016).

45. Hershfield MS, Callaghan JT, Tassaneeyakul W et al. Clinical Pharmacogenetics Implementation Consortium guidelines for human leukocyte antigen-B genotype and allopurinol dosing. Clin. Pharmacol. Ther. 93(2), 153-158 (2013).

46. Lee MT, Mahasirimongkol S, Zhang Y et al. Clinical application of pharmacogenomics: the example of HLA-based drug-induced toxicity. Public Health Genomics 17(5-6), 248-255 (2014).

47. Cheng CY, Su SC, Chen CH, Chen WL, Deng ST, Chung WH. HLA associations and clinical implications in T-cell mediated drug hypersensitivity reactions: an updated review. J. Immunol. Res. 2014, 565320 (2014).

48. Hung SI, Chung WH, Liou LB et al. HLA-B in situ 5801 allele as a genetic marker for severe cutaneous adverse reactions caused by allopurinol. Proc. Natl. Acad. Sci. USA 102(11), 4134-4139 (2005).

- First identification of the association between HLA-B in situ 5801 and allopurinol-related severe cutaneous reactions.

49. Tohkin M, Kaniwa N, Saito Y et al. A whole-genome association study of major determinants for allopurinol-related Stevens-Johnson syndrome and toxic epidermal necrolysis in Japanese patients. Pharmacogenomics J. 13(1), 60-69 (2013).

50. Tassaneeyakul W, Jantararoungtong T, Chen P et al. Strong association between HLA-B in situ 5801 and allopurinol-induced Stevens-Johnson syndrome and toxic epidermal necrolysis in a Thai population. Pharmacogenet. Genomics 19(9), 704-709 (2009).

51. Cao ZH, Wei ZY, Zhu QY et al. HLA-B in situ 58:01 allele is associated with augmented risk for both mild and severe cutaneous adverse reactions induced by allopurinol in Han Chinese. Pharmacogenomics 13(10), 1193-1201 (2012).

52. Kaniwa N, Saito Y, Aihara M et al. HLA-B locus in Japanese patients with anti-epileptics and allopurinol-related Stevens-Johnson syndrome and toxic epidermal necrolysis. Pharmacogenomics 9(11), 1617-1622 (2008). 
53. Lonjou C, Borot N, Sekula P et al. A European study of HLA-B in Stevens-Johnson syndrome and toxic epidermal necrolysis related to five high-risk drugs. Pharmacogenet. Genomics 18(2), 99-107 (2008).

54. Somkrua R, Eickman EE, Saokaew S, Lohitnavy M, Chaiyakunapruk N. Association of HLA-B in situ 5801 allele and allopurinol-induced Stevens-Johnson syndrome and toxic epidermal necrolysis: a systematic review and meta-analysis. BMC Med. Genet. 12, 118 (2011).

55. Yun J, Mattsson J, Schnyder K et al. Allopurinol hypersensitivity is primarily mediated by dose-dependent oxypurinol-specific T-cell response. Clin. Exp. Allergy 43(11), 1246-1255 (2013).

56. Khanna D, Fitzgerald JD, Khanna PP et al. 2012 American College of Rheumatology guidelines for management of gout. Part 1: systematic nonpharmacologic and pharmacologic therapeutic approaches to hyperuricemia. Arthritis Care Res. (Hoboken) 64(10), 1431-1446 (2012).

57. Phillips EJ, Mallal SA. Pharmacogenetics of drug hypersensitivity. Pharmacogenomics 11(7), 973-987 (2010).

- Excellent review focusing on the requirements for successful implementation of HLA testings into routine clinical care.

58. Chung WH, Hung SI, Hong HS et al. Medical genetics: a marker for Stevens-Johnson syndrome. Nature 428(6982), 486 (2004).

- First identification of the association between HLA-B in situ 1502 and carbamazepine-induced severe cutaneous reactions.

59. Chung WH, Hung SI. Recent advances in the genetics and immunology of Stevens-Johnson syndrome and toxic epidermal necrosis. J. Dermatol. Sci. 66(3), 190-196 (2012).

60. Man CB, Kwan P, Baum L et al. Association between HLA-B in situ 1502 allele and antiepileptic drug-induced cutaneous reactions in Han Chinese. Epilepsia 48(5), 1015-1018 (2007).

61. Wu XT, Hu FY, An DM et al. Association between carbamazepine-induced cutaneous adverse drug reactions and the HLA-B in situ 1502 allele among patients in central China. Epilepsy Behav. 19(3), 405-408 (2010).

62. Wang Q, Zhou JQ, Zhou LM et al. Association between HLA-B in situ 1502 allele and carbamazepine-induced severe cutaneous adverse reactions in Han people of southern China mainland. Seizure 20(6), 446-448 (2011).

63. Tassaneeyakul W, Tiamkao S, Jantararoungtong T et al. Association between HLA-B in situ 1502 and carbamazepine-induced severe cutaneous adverse drug reactions in a Thai population. Epilepsia 51(5), 926-930 (2010).

64. Locharernkul C, Loplumlert J, Limotai C et al. Carbamazepine and phenytoin induced Stevens-Johnson syndrome is associated with HLA-B in situ 1502 allele in Thai population. Epilepsia 49(12), 2087-2091 (2008).

65. Then SM, Rani ZZ, Raymond AA, Ratnaningrum S, Jamal R. Frequency of the HLA-B in situ 1502 allele contributing to carbamazepine-induced hypersensitivity reactions in a cohort of Malaysian epilepsy patients. Asian Pac. J. Allergy Immunol. 29(3), 290-293 (2011).

66. Mehta TY, Prajapati LM, Mittal B et al. Association of HLA-B in situ 1502 allele and carbamazepine-induced Stevens-Johnson syndrome among Indians. Indian J. Dermatol. Venereol. Leprol. 75(6), 579-582 (2009).

67. Kulkantrakorn K, Tassaneeyakul W, Tiamkao S et al. HLA-B in situ 1502 strongly predicts carbamazepine-induced Stevens-Johnson syndrome and toxic epidermal necrolysis in Thai patients with neuropathic pain. Pain Pract. 12(3), 202-208 (2012).

68. Grover S, Kukreti R. HLA alleles and hypersensitivity to carbamazepine: an updated systematic review with meta-analysis. Pharmacogenet. Genomics 24(2), 94-112 (2014).

69. Tangamornsuksan W, Chaiyakunapruk N, Somkrua R, Lohitnavy M, Tassaneeyakul W. Relationship between the HLA-B in situ 1502 allele and carbamazepine-induced Stevens-Johnson syndrome and toxic epidermal necrolysis: a systematic review and meta-analysis. JAMA Dermatol. 149(9), 1025-1032 (2013).

70. Bloch KM, Sills GJ, Pirmohamed M, Alfirevic A. Pharmacogenetics of antiepileptic drug-induced hypersensitivity. Pharmacogenomics 15(6), 857-868 (2014).

71. Chen P, Lin JJ, Lu CS et al. Carbamazepine-induced toxic effects and HLA-B in situ 1502 screening in Taiwan. N. Engl. J. Med. 364(12), 1126-1133 (2011).

- Large prospective study demonstrating the benefits of HLA-B in situ 15:02 pretreatment screening in preventing carbamazepine-related severe cutaneous reactions.

72. Ko TM, Chung WH, Wei CY et al. Shared and restricted T-cell receptor use is crucial for carbamazepine-induced Stevens-Johnson syndrome. J. Allergy Clin. Immunol. 128(6), 1266-1276 (2011).

73. Ozeki T, Mushiroda T, Yowang A et al. Genome-wide association study identifies HLA-A in situ 3101 allele as a genetic risk factor for carbamazepine-induced cutaneous adverse drug reactions in Japanese population. Hum. Mol. Genet. 20(5), 1034-1041 (2011).

74. Mccormack M, Alfirevic A, Bourgeois S et al. HLA-A in situ 3101 and carbamazepine-induced hypersensitivity reactions in Europeans. N. Engl. J. Med. 364(12), 1134-1143 (2011).

75. Alfirevic A, Jorgensen AL, Williamson PR, Chadwick DW, Park BK, Pirmohamed M. HLA-B locus in Caucasian patients with carbamazepine hypersensitivity. Pharmacogenomics 7(6), 813-818 (2006).

76. Niihara H, Kakamu T, Fujita Y, Kaneko S, Morita E. HLA-A31 strongly associates with carbamazepine-induced adverse drug reactions but not with carbamazepine-induced lymphocyte proliferation in a Japanese population. J. Dermatol. 39(7), 594-601 (2012). 
77. Hung SI, Chung WH, Jee SH et al. Genetic susceptibility to carbamazepine-induced cutaneous adverse drug reactions. Pharmacogenet. Genomics 16(4), 297-306 (2006).

78. Wei CY, Chung WH, Huang HW, Chen YT, Hung SI. Direct interaction between HLA-B and carbamazepine activates T cells in patients with Stevens-Johnson syndrome. J. Allergy Clin. Immunol. 129(6), 1562-1569 (2012).

79. Sukasem C, Puangpetch A, Medhasi S, Tassaneeyakul W. Pharmacogenomics of drug-induced hypersensitivity reactions: challenges, opportunities and clinical implementation. Asian Pac. J. Allergy Immunol. 32(2), 111-123 (2014).

80. Amstutz U, Shear NH, Rieder MJ et al. Recommendations for HLA-B in situ 15:02 and HLA-A in situ 31:01 genetic testing to reduce the risk of carbamazepine-induced hypersensitivity reactions. Epilepsia 55(4), 496-506 (2014).

81. Yip VL, Pirmohamed M. The HLA-A in situ 31:01 allele: influence on carbamazepine treatment. Pharmgenomics Pers. Med. 10, 29-38 (2017).

- An in-depth analysis of the clinical translability of HLA-A in situ 31:01 genotyping in the context of carbamazepine-induced hypersensitivity reactions.

82. Hung SI, Chung WH, Liu ZS et al. Common risk allele in aromatic antiepileptic-drug induced Stevens-Johnson syndrome and toxic epidermal necrolysis in Han Chinese. Pharmacogenomics 11(3), 349-356 (2010).

83. Liao WP, Shi YW, Min FL. HLA-B in situ 1502 screening and toxic effects of carbamazepine. N. Engl. J. Med. 365(7), 672-673 (2011).

84. Plumpton CO, Roberts D, Pirmohamed M, Hughes DA. A systematic review of economic evaluations of pharmacogenetic testing for prevention of adverse drug reactions. Pharmacoeconomics 34(8), 771-793 (2016).

- An up-to-date review on the cost-effectiveness of pharmacogenomic testing for prevention of drug-induced hypersensitivity reactions.

85. Whirl-Carrillo M, Mcdonagh EM, Hebert JM et al. Pharmacogenomics knowledge for personalized medicine. Clin. Pharmacol. Ther. 92(4), 414-417 (2012).

86. PharmGBK. www.pharmgkb.org/

87. Pirmohamed M. Acceptance of biomarker-based tests for application in clinical practice: criteria and obstacles. Clin. Pharmacol. Ther. 88(6), 862-866 (2010).

88. Alfirevic A, Pirmohamed M. Genomics of adverse drug reactions. Trends Pharmacol. Sci. 38(1), 100-109 (2017).

89. Lauschke VM, Ingelman-Sundberg M. Requirements for comprehensive pharmacogenetic genotyping platforms. Pharmacogenomics 17(8), 917-924 (2016).

90. St Sauver JL, Bielinski SJ, Olson JE et al. Integrating pharmacogenomics into clinical practice: promise vs reality. Am. J. Med. 129(10), 1093-1099 (2016).

91. Yun J, Adam J, Yerly D, Pichler WJ. Human leukocyte antigens (HLA) associated drug hypersensitivity: consequences of drug binding to HLA. Allergy 67(11), 1338-1346 (2012).

92. Bharadwaj M, Illing P, Kostenko L. Personalized medicine for HLA-associated drug-hypersensitivity reactions. Personalized Med. 7(5), 495-516 (2010).

93. Karlin E, Phillips E. Genotyping for severe drug hypersensitivity. Curr. Allergy Asthma Rep. 14(3), 418 (2014).

94. Alfirevic A, Pirmohamed M. Predictive genetic testing for drug-induced liver injury: considerations of clinical utility. Clin. Pharmacol. Ther. 92(3), 376-380 (2012).

95. Bjornsson ES, Bergmann OM, Bjornsson HK, Kvaran RB, Olafsson S. Incidence, presentation, and outcomes in patients with drug-induced liver injury in the general population of Iceland. Gastroenterology 144(7), 1419-1425 (2013).

96. Becquemont L. HLA: a pharmacogenomics success story. Pharmacogenomics 11(3), 277-281 (2010).

97. Sharon E, Streicher H, Goncalves P, Chen HX. Immune checkpoint inhibitors in clinical trials. Chinese J. Cancer 33(9), 434-444 (2014).

98. Roberts K, Culleton V, Lwin Z, O’Byrne K, Hughes BG. Immune checkpoint inhibitors: navigating a new paradigm of treatment toxicities. Asia Pac. J. Clin. Oncol. 13(4), 277-288 (2017).

99. Ciccarese $\mathrm{C}$, Alfieri $\mathrm{S}$, Santoni $\mathrm{M}$ et al. New toxicity profile for novel immunotherapy agents: focus on immune-checkpoint inhibitors. Expert Opin. Drug Metab. Toxicol. 12(1), 57-75 (2016).

100. Demlova R, Valik D, Obermannova R, Zdrazilova-Dubska L. The safety of therapeutic monoclonal antibodies: implications for cancer therapy including immuno-checkpoint inhibitors. Physiol. Res. 65(Suppl. 4), S455-S462 (2016). 
